\title{
PROVIDING LONGITUDINAL CONNECTION IN CASE OF CROSS SLUICING ON WATER BODIES IN BANAT HYDROGRAPHIC AREA
}

\author{
Diana HOANC $\breve{A}$ *, Corina TODORESCU * and Alina ROŞU * \\ * National Administration "Apele Romane" Banat Water Basin Administration, River Basin \\ Management Plan Office, Mihai Viteazul Boulevard 32, Timişoara, Timiş County, Romania, RO- \\ 300222,diana.hoanca@dab.rowater.ro, corina.todorescu@dab.rowater.ro, alina.rosu@dab.rowater.ro
}

DOI: 10.1515/trser-2015-0024

KEYWORDS: hydromorphological alterations, impact, longitudinal connection.

\section{ABSTRACT}

On Banat Hydrographic Area level, there are a series of works which put hydrological pressures on bodies of water: accumulations, damming, water diversions, regulations, shore protection, etc. These works were created in order to ensure water demand, defend against floods, regulate discharges, and combat humidity excess. Speaking justly, they have an important socioeconomic role. Among the negative effects of longitudinal connection interruption of water bodies we can mention, the risk of not achieving the positive ecological potential of water bodies in accordance with the Water Framework Directive, the reduction of the aquatic biodiversity, the reduction or even extinction of certain aquatic species and the alteration of the flow process. Because the negative effects of the hydromorphological alterations, especially those due to the interruption of the longitudinal connection, have a significant impact on the aquatic biodiversity. At Banat Hydrographic Area level, a series of measures, have been identified for the rehabilitation of the affected water courses: the removal of the hydrotechnical constructions from the water body if they have lost their functional features, building of passages for the migration of the ichthyofauna, reconnecting of the affluents and the disconnected arms as well as other measures intended to bring things back to their natural state. The implementation of these measures is made according to the importance and the extent of their positive impact as opposed to the negative effect that might occur as a consequence of their application. Analyzing the measures aforementioned and taking into consideration the characteristics of the hydromorphological pressures on water bodies in Banat Hydrographic Area, a number of measures regarding control are supplied in this paper.

RESUMEN: Conectividad longitudinal mediante exclusas en cuerpos de agua de la Cuenca Hidrográfica de Banat.

En cuanto a la Cuenca Hidrográfica de Banat, existe cantidad de infraestructuras que presentan presión hidrológica sobre los cuerpos de agua: estructuras de acumulación, embalses, desviaciones de agua, reguladores, protecciones costeras, etc. Estos trabajos fueron creados con el fin de asegurar la demanda de agua, defensa contra inundaciones, regulación de las descargas, combate contra el exceso de humedad, y por ello han tenido un papel socioeconómico relevante. Entre los efectos negativos que ha tenido la interrupción de la conectividad entre los cuerpos de agua, se puede mencionar el riesgo de comprometer el potencial ecológico de los cuerpos de agua en los términos que se definen en la Directiva antes mencionada, la reducción de la biodiversidad acuática, la disminución e incluso la extinción de ciertas especies acuáticas y la alteración del flujo de agua. En virtud de los efectos que tienen las alteraciones hidrogeomorfológicas, especialmente aquellas que interrumpen la conexión 
longitudinal, la biodiversidad acuática se ha visto negativamente impactada en la Cuenca Hidrográfica de Banat. A este respecto se han identificado una serie de medidas tendientes a la rehabilitación de los cursos de agua más afectados, como la remoción de construcciones hidrotécnicas de los cuerpos de agua si estas han perdido sus rasgos funcionales básicos, construcción de pasajes migratorios para la ictiofauna, reconexión de afluentes y de tributarios inconexos, así como también otras medidas cuya finalidad sea restablecer las condiciones alteradas a su estado original. La implementación de estas medidas se hace de acuerdo a la importancia y la extensión de los impactos positivos esperados en balance a los impactos negativos que pudieran suceder tras su aplicación. El análisis de estas acciones y la consideración de las características de las presiones hidrogeomorfológicas sobre los cuerpos de agua en la Cuenca Hidrográfica de Banat que se presentan en este trabajo, han sido consideradas como adecuadas.

REZUMAT: Asigurarea conectivităţii longitudinale în cazul barărilor transversale pe corpurile de apă din spaţiul hidrografic Banat.

La nivelul Spaţiului Hidrografic Banat se găsesc o serie de lucrări care exercită presiuni hidromorfologice asupra corpurilor de apă: acumulări, îndiguiri, derivaţii, regularizări, apărări de maluri, etc. Aceste lucrări au fost create pentru asigurarea cerinţei de apă, apărare împotriva inundaţiilor, regularizarea debitelor, combaterea excesului de umiditate şi au un rol socio-economic important.

Dintre efectele negative ale întreruperii conectivităţii longitudinale a cursurilor de apă amintim: riscul de a nu atinge starea/potenţialul ecologic bun al corpurilor de apă conform Directivei Cadru a Apei, reducerea biodiversităţii acvatice, reducerea efectivelor sau chiar dispariţia unor specii acvatice, modificarea regimului curgerii.

Deoarece efectele negative datorate alterărilor hidromorfologice, în special celor datorate întreruperii conectivităţii longitudinale, au un impact semnificativ asupra biodiversităţii acvatice, la nivelul Spaţiului Hidrografic Banat s-au identificat o serie de măsuri de reabilitare a cursurilor de apă afectate: eliminarea de pe corpul de apă respectiv a construcţiilor hidrotehnice dacă acestea şi-au pierdut funcţionalitatea, executarea de pasaje pentru migrarea ihtiofaunei, reconectarea afluenţilor şi a braţelor deconectate, alte măsuri, prin care se revine la starea naturală. Aplicarea acestor măsuri se face în funcţie de importanţa şi mărimea impactului pozitiv în comparaţie cu efectul negativ, care ar putea să apară ca o consecinţă a aplicării lor. Analizând măsurile prezentate anterior şi luând în considerare caracteristicile presiunilor hidromorfologice ale corpurilor de apă din SH Banat s-au considerat pertinente o serie de măsuri care sunt prezentate în lucrarea de faţă.

\section{INTRODUCTION}

The Water Framework Directive 2000/60/EC represent the document through which the European Union establishes a community framework for the protection and management of water. It was adopted by the European Parliament on 23 October 2000 and its main objective is maintaining both surface and underground water bodies in "good condition" until 2015.

The Management Plan of the Hydrographic Area represents the instrument through which the Water Framework Directive is implemented and has as purpose the balanced management of water resources as well as the protection of the aquatic ecosystems.

The target area of this scientific paper is under a significant historical human impact influence (Burghelea et al., 2013) one more reason for such a study. 


\section{The risk of failure in achieving the environmental objectives}

According to the 5th article in the Framework Directive which stipulates that "Each Member State must mention the impact of human activities on the condition of surface and underground waters”, it is necessary to perform an assessment of the anthropic pressures and their impact on the level of water bodies, which may lead to identifying those water bodies which fail to achieve the objectives of the Framework.

The identified risk categories at the level of surface and underground water bodies are: organic substances pollution, nutrient pollution, dangerous substances pollution, hydromorphological alterations.

\section{Hydromorphological pressures on water bodies}

Water bodies are considered strongly modified when the normal environmental condition cannot be achieved because of the impact of the physical modifications of the hydromorphological characteristics of surface waters.

Hydromorphological alterations represent one of the most important pressures with impact on water resources and they are the consequence of different types of constructions on waters or closely dependent of water bodies. This type of pressure influences the hydromorphological characteristics specific to surface waters and produces a negative impact on the condition of aquatic ecosystems. These constructions consist mainly of dams, flood stops and crossings and they interrupt the longitudinal connection of rivers, exercising negative effect pressures on the hydrological condition, on the sediment transportation and on biota migration. Other types of works which are made along the river, such as dammings, regulations and consolidation of shores, interrupt the lateral connections of the water bodies.

Thus, the impact of hydromorphological alterations on the condition of water bodies can be seen in the change of migratory fish species, the decline of natural reproduction of fish populations, the reduction of biodiversity and species abundance as well as the alteration of populations' composition. The hydromorphological pressures to which also other types of pressures are added, act collaboratively and therefore multiply the consequences.

\section{General presentation of the Banat Hydrographic Area}

The Banat Hydrographic Area is composed of six main hydrographic basins as well as the hydrographic basins of Danube's left affluents, between Nerei and Cernei basins. The length of the hydrographic network is about $6,245 \mathrm{~km}$ to which there are added $145 \mathrm{~km}$, the length of the Danube bordering the Banat HA. There are also 389 rivers whose basin-surface is larger than $10 \mathrm{~km}^{2}$.

The hydrographic basins of category I in the Banat HA are: Aranca, Bega, Timiş, Caraș, Nera, Cerna and Danube.

At the level of the Banat Hydrographic Area, different types of land features can be found: the highest altitude is in the south-west part (Godeanu Mountains, maximum altitude of 2,229 $\mathrm{m}$ ) and the lowest one towards the north-west part (Banatului Plane, minimum altitude of $77 \mathrm{~m}$ in the border area).

In the Banat HA, the lakes has a surface biger than $0.5 \mathrm{~km}^{2}$ are nine and all of them are dam lakes. They are mainly found in Timiș, Bega, Caraș and Cerna basins, and have been built in order to provide water for consumption, industrial purposes, energy purposes and defense against floods. 


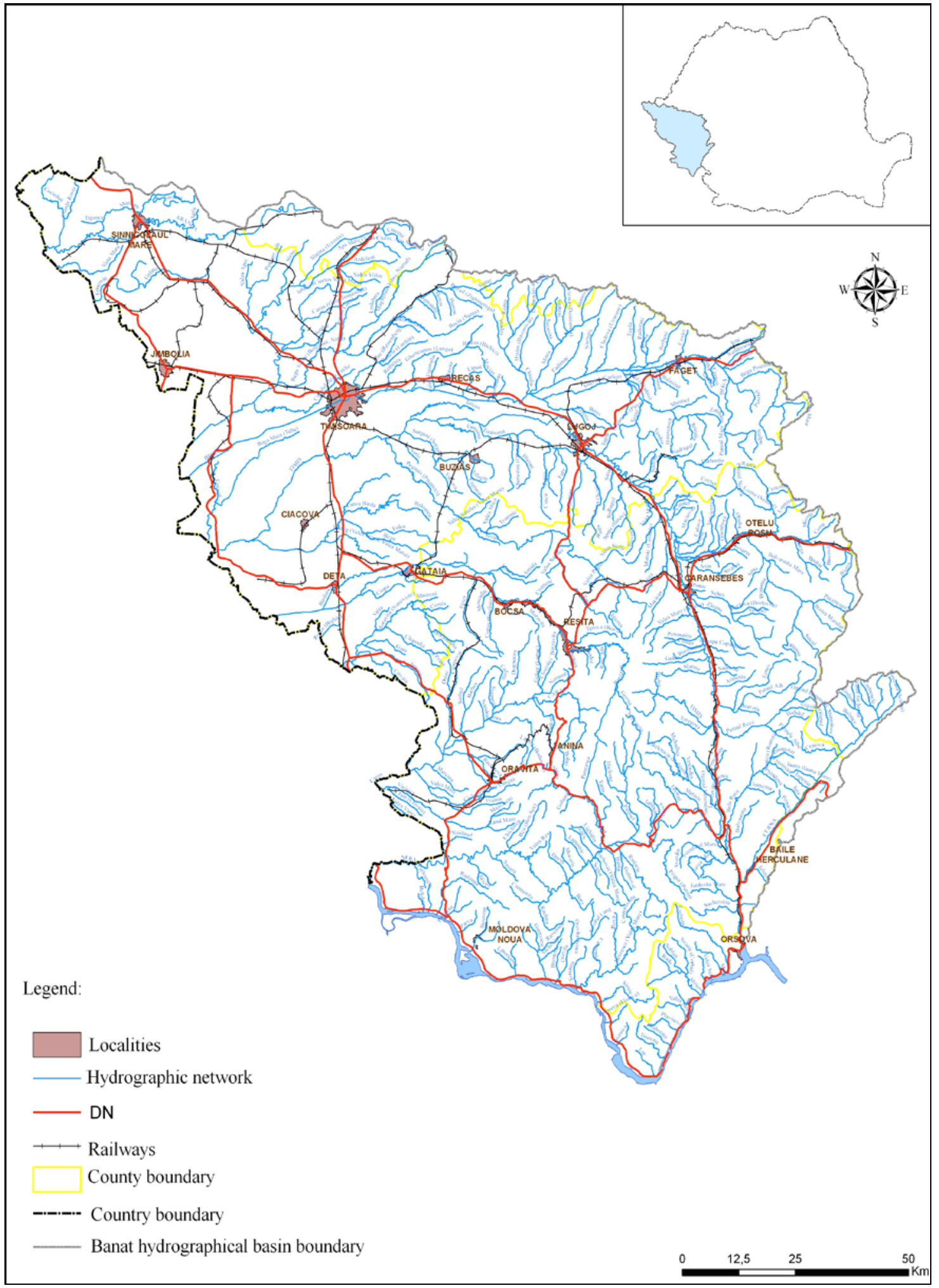

Figure 1: Banat Hydrographic Area. 


\section{Hydromorphological pressures at the level of Banat HA}

At the level of the Banat Hydrographic Area there are different work categories which exercise hydromorphological pressures on water bodies. These are: accumulations, dammings, water diversions, regulations, shore protection, etc.

These works have been made for various purposes. The most notable is to ensure the demand for drinkable and industrial water. Others include energy use, flood defense, flow regulation, and fighting humidity excess, etc., all these being of social-economic importance.

The barrier lakes within the Banat Hydrographic Area represent a hydromorphological pressure because they interrupt the longitudinal connection of the flow. The existing barriers are as follows: Murani, Poiana Mărului, Gozna, Iovan's Valley, Herculane, Surduc, Secul, Trei Ape, and Rusca.

Regarding regulations and dammings, these are found in an area of 64 stream sections, having a total length of $699 \mathrm{~km}$. There are 126 dammings of 1,049 km in length, out of which only 17 can be considered significant hydromorphological pressures, of $435.3 \mathrm{~km}$ in total length, and which are responsible for the interruption of the lateral connection of water bodies.

There are eight derivations and their purpose is to supplement the flows in sections, with a necessary water higher than the natural potential of the river. These derivations can cause both hydrological and environmental unbalances.

The passable canals are represented by a single passable route, the Bega Canal. Navigation on Bega canal determines a series of significant hydromorphological pressures on this ecosystem.

The significant water disposals in Banat HA produce quantitatively important hydromorphological alterations.

All these hydromorphological alterations contribute to the interruption of: longitudinal connection of watercourses, caused by hydrotechnical works such as dams, crossings, barriers; lateral connection of watercourses, caused by dammings, riverbed regulation works, shore consolidations.

\section{The study of ichthyofauna migration in Banat Hydrographic Area}

The EFI+ research project was made in order to acquire new knowledge and develop and improve new methods of biological assessment based on ichthyofauna. These are all necessary to meet the demands of the Water Framework Directive and applicable, as new methods, to all EU member states as well as to the pending ones.

According to the EFI+ list of medium distance migratory fish, in Banat HA we find the following migratory species: Abramis brama (bream), Abramis sapa (Danube bream), Aspius aspius (rapacious carp), Barbus barbus (barbell), Chondrostoma nasus (broad snout), Lota lota (burbot), and Vimba vimba (codling).

As a result of analyses carried out between 2005-2012, in Banat HA there was registered the presence of migratory species in 42 water bodies corresponding to the six hydrographic basins, as well as at the level of the sector in the Danube's hydrographic basin, as follows: Timiș Hydrographic Basin: 14 water bodies, Bega Hydrographic Basin: nine water bodies, Caraș Hydrographic Basin: seven water bodies, Nera Hydrographic Basin: five water bodies, Cerna Hydrographic Basin: four water bodies, Danube Hydrographic Basin: two water bodies; Aranca Hydrographic Basin: one water body. 


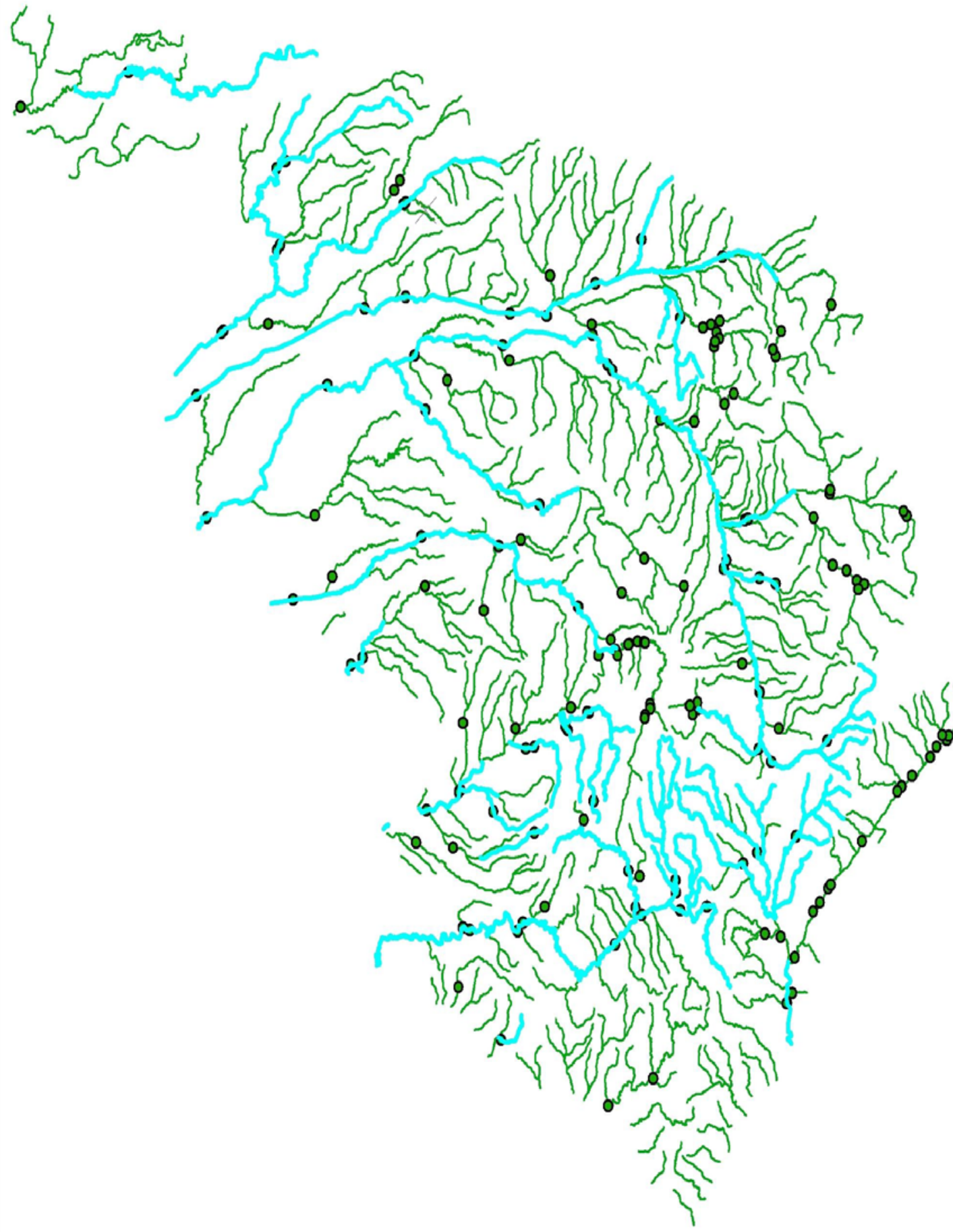

Figure 2: Fish migration, according to assays made between 2005-2012. 
Measures to rehabilitate the longitudinal connection of rivers in the Banat HA

Following the target of a good water condition and good potential of water bodies, the Water Framework Directive sets the basis of a new strategy in managing waters, a strategy which takes into consideration new elements, inlcuding the rehabilitation of water resources. The research performed showed that the interruption of the longitudinal and lateral connection of watercourses leads, in time, to the reduction of the aquatic environment biodiversity. The negative effects of longitudinal connection interruption of watercourses because of cross barriers on water bodies are: the risk of not achieving the good environmental condition/good environmental potential; the reduction as well as the modification of natural reproduction of fish populations; the alteration of the flowing process.

Establishing the longitudinal connection of the watercourse is necessary, taking into consideration its effects on the aquatic biodiversity; in order to attain this, one could chose one of the following measures: the removal of the existing hydrotechnical constructions on the watercourse if these have lost their function; the building of passes for the migration of the ichthyofauna (bypass canals, incline-decline systems, fish elevators) if in those waters there are migratory fish species and if the existing obstacles have more than $30 \mathrm{~cm}$ in height for cyprinids and $50 \mathrm{~cm}$ for salmonids; the reconnection of affluents and of disconnected arms natural or built; other measures aiming mainly at re-establishing the natural condition.

After identifying the rehabilitation measures for the water bodies in the Banat Hydrographic Area, their implementation is made according to each type of morphological alteration existing in that water body. Considering the importance and size of the positive impact that these measures have is of great concern. This is done by comparison to the negative effects that could appear as a result of these measures.

Analysing the presented measures and taking into consideration the characteristics of the hydromorphological pressures on water bodies in the Banat HA, the following have been considered to ensure longitudinal connection: the creation of a bypass on Bega watercourse, at Balint Watermill - periodically functional and where there is a four meters high dam.

This measure is most suited on the left bank and its implementation eases the access of migratory ichthyofauna on medium distances.

- $\quad$ the closing down of the crossing at Chizătău Watermill, on Bega River, as it is unfunctional for its purpose, having free flow;

- $\quad$ the removal of the cross barrier at Petroşnița Watermill, on Timiș River;

- $\quad$ the creation of a bypass, starting with a pipe through the dam, on Bega watercourse at the Topolovăt Hydrotechic Knot which is fully used (hydroenergetically, irrigations and defense against floods);

- $\quad$ the building of fish ladder on Bega at UHE Timişoara;

- the removal of the cross barrier at Sadova Veche Watermill on Timiş watercourse;

- the creation of a gap of $0.5 \mathrm{~m}$ in the crossing or a fish ladder on Bistra River at CHE Glimboca;

- $\quad$ the creation of a bypass on Caraș River at Vrani Watermill - functional;

- $\quad$ the relieving and partial cleaning of Timiș River waterbed at MHC Constantin

Daicoviciu as it is unfunctional because the crossing and the feed canal are destroyed 75\%;

- the building of a fish passage on Timiș River at Coştei Hydrotechnic Knot; crossings in Cotul Mic. the building of a fish ladder on both banks on Timiș River aligned against the 


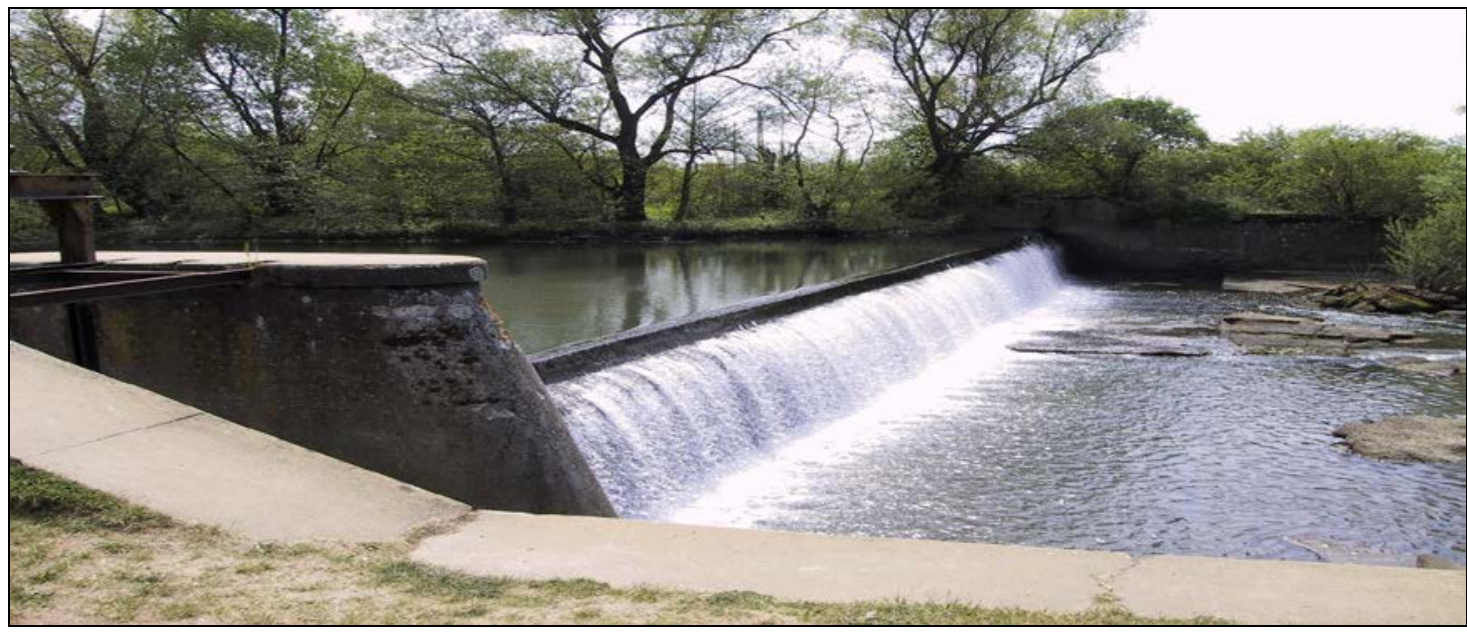

Figure 3: Balint Watermill sector.

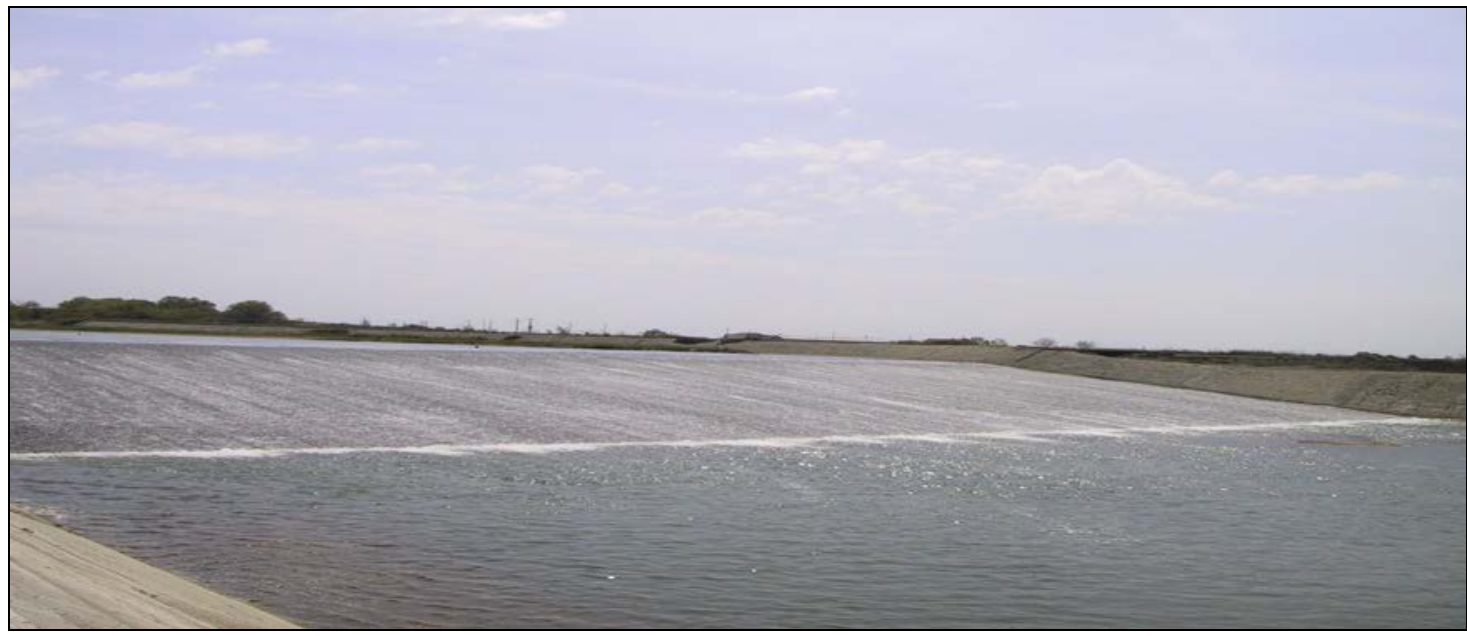

Figure 4: Hydrotechnic Knot in Coştei.

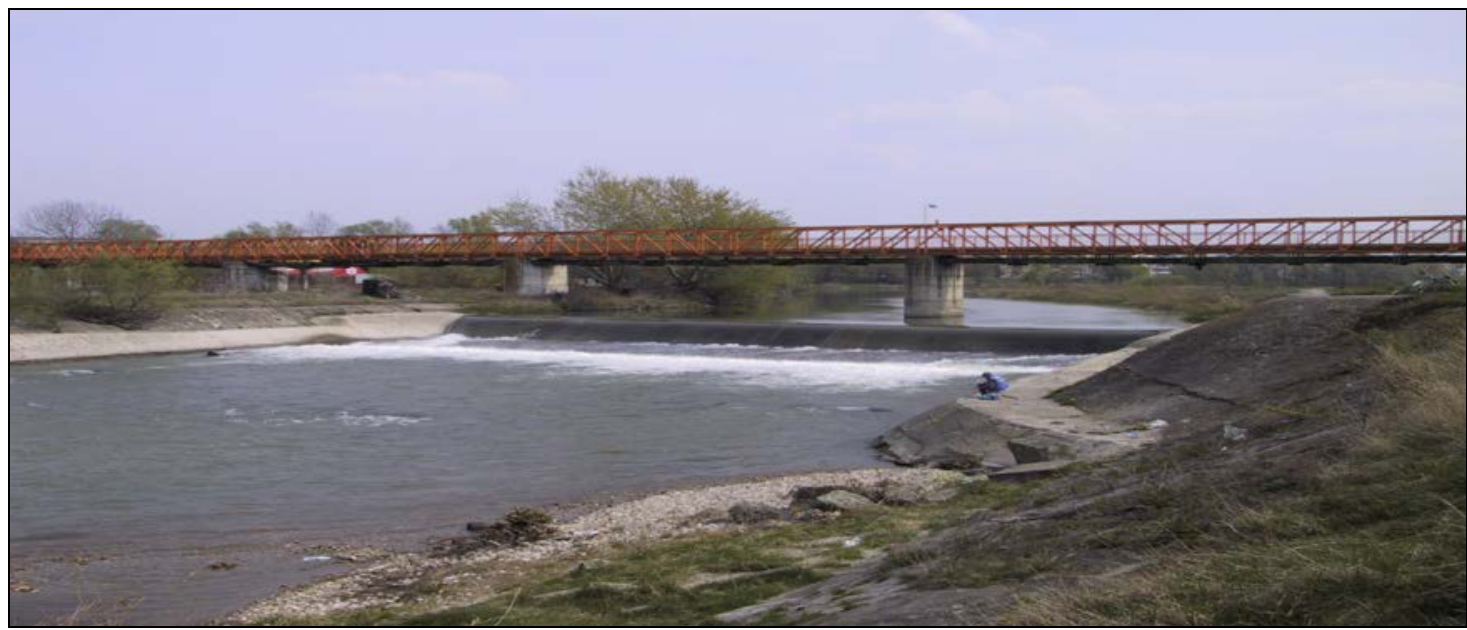

Figure 5: Crossing in Cotul Mic. 


\section{CONCLUSIONS}

The identification of rehabilitation measures of the longitudinal connection for water bodies within Banat Hydrographic Area was performed individually for each type of hydromorphological alteration found at the level of the hydrographic space. The river water bodies were analyzed and the existence of migratory fish species and those whose migration is hindered by the cross sluicings present on water were taken into consideration. Also, the specific characteristics of the area, including specific features of the body of water and its uses were not discarded. The measures to be taken were agreed upon as a result of the correlations of the field data with the ones in the databases.

The most important effects of ensuring longitudinal connection of water bodies are the following: the improvement of their condition/of their environmental potential, the reestablishment of the aquatic habitats that have been affected, the increase in abundance of aquatic species especially of the ichthyofauna, etc. 


\section{REFERENCES}

1. Bănărescu P., 1964 - Fauna Republicii Populare Române, Pisces, Osteichthyes, XIII, Edit. Academiei Române, București, 935. (in Romanian)

2. Burghelea B., Bănăduc D. and Curtean-Bănăduc A., 2013 - Transylvanian Review of Systematical and Ecological Research, 15, The Timiș River Basin, The Timiș River basin (Banat, Romania) natural and anthropogenic elements. A study case - management challenges, 173-206.

3. ***, 2011 - “Annual summary of water quality protection”, Service Management, Monitoring and Protection of water resources ABAB, Timişoara, 120.

4. ***, 2009 - "Banat River Basin Management Plan” („Planul de Management al Spaţiului Hidrografic Banat”), River Basin Management Plan, ABAB, Timişoara, 235.

5. Şerban P. and Gălie A., 2007 - Study on "Measures to restore connection longitudinal and lateral water bodies identified as heavily modified preliminary”, 53.

6. $\quad * * *, 2000$ - "Water Framework Directive” („Directiva Cadru în domeniul apei”) 2000/60/EC, Grupul de Lucru al Parlamentului European şi Consiliului Uniunii Europene, Luxemburg.

7. ***, 1992 - Water Cadastre Atlas of Romania, Ministry of Environment and “AQUAPROIECT” S. A., Bucureşti. 